\title{
FLORIDA 4-H RECORD BOOK
}

\section{Poultry Project}

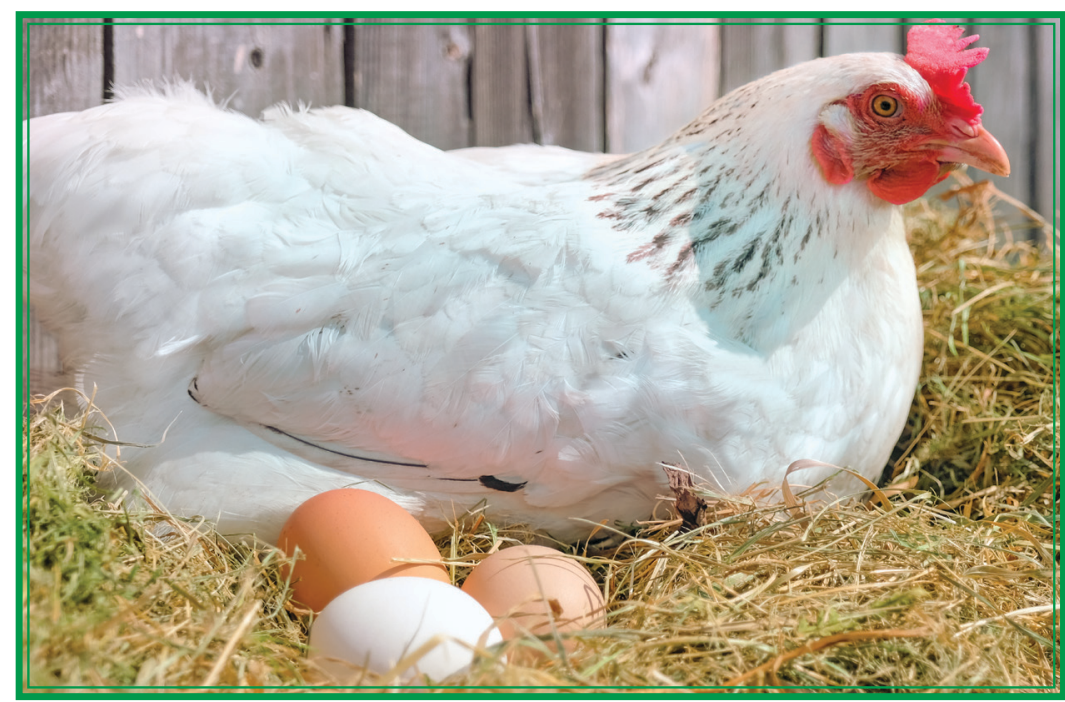

Credit: Anastasiia Magonova/gettyimages.com

Name

Age (as of Sept. 1)

County 4-H Club

Breed(s) of Poultry

Record Started

$\overline{\text { Month }} \overline{\text { Day }} \overline{\text { Year }}$

Record Closed

Month $\overline{\text { Day }} \overline{\text { Year }}$

I hereby certify that as the exhibitor of this project, I have personally kept records on this project and have personally completed this record book.

Signed

Member

Date

This youth is an active member of the 4-H Club. This record book has been completed by the youth and is an accurate record of the project.

Signed 


\section{Youth Poultry Project Agreement}

\section{(to be completed at the beginning of the project)}

The youth is responsible for caring for the birds, which will include feeding, basic health care, providing fresh and clean water, providing a proper pen or housing, washing, and exhibiting the animals. The youth will use this project as an educational tool to learn skills needed in the livestock industry. This project will also help the youth to accept success and failure as a learning experience. The youth will keep accurate records on their project birds.

I accept these responsibilities

Member Date

The parent/guardian is responsible for providing financial help, if needed, along with assistance and encouragement while the youth is raising the birds.

I accept these responsibilities

Signature of Parent or Caretaker Date

\section{Drug Statement}

I hereby certify that any drug, antibiotic, or biological substance that may have been administered by myself or any other person was done in strict compliance with the manufacturer's label requirements.

Signature of Youth

Date

Signature of Parent or Caretaker

Date 


\section{Purpose}

The purpose of the 4-H poultry project is to achieve the following:

- To acquire an understanding of poultry production by preparing for, purchasing, breeding, caring for, and keeping records on one or more chickens or other poultry species as a part of a $4-\mathrm{H}$ project.

- To be able to identify the types and breeds of poultry and employ efficient methods of production and marketing.

- To understand the business aspects and economics of purchasing poultry animals, feed, facilities, and equipment for a poultry project.

- To develop life skills and workforce preparedness skills such as responsibility, integrity, sportsmanship, development of a strong work ethic, and cooperation.

- To develop leadership abilities, build character, and become responsible citizens.

- To apply science, engineering, and technology skills to their projects.

- To develop science literacy.

- To pursue education and careers related to science

\section{Why Keep Records}

- To have an account of all of your 4-H accomplishments in one place.

- To point out the advantages and disadvantages of projects.

- To reflect your interest as a 4-H club member.

- To show self-improvement and service to others.

- To publicize.

- To show others what you have done.

- To train yourself for future work.

- To qualify for camp, 4-H University, contests, and awards.

\section{General Rules for 4-H Club Members Participating in the Poultry Project}

1. Members must be at least 8 and not over 18 years of age as of September 1 of the project year.

2.Members must do as much of the work themselves as possible.

3. Members must complete record books as instructed.

4. Members must write a story of the year's work in record books.

5.Members must attend all meetings and as many countylevel events as possible.

6. Members must take or send record books to 4-H Youth Development Agent when requested.

7. All members must make exhibits or give demonstrations when they can.

8. The 4-H Youth Development Agent will state how small a project may be in the county.

9. The 4-H Youth Development Agent supervises 4-H project work in the county. He or she may be assisted by the local leader.

\section{How to Keep This Poultry Record}

1.At the start of the project:

a. The first thing you should do is study this record book carefully.

b. Fill in the cover page, poultry project agreement, and the drug statement on page 2 .

c. Fill in figures under "Beginning of Record" at top of page 5.

d.Fill in information under "Day-Old Chicks Started" on page 5 when you purchase or start baby chicks.

e. List all equipment, feed, and other expenses to date on pages $7-9$. 
2.Each time you buy or are given feed, medicines, or equipment, be sure to enter it in the record under expenses on pages 7-9.

3. Each time you sell or use on the farm any eggs, chickens, manure, etc., be sure to enter it under income on page 11 , or products used on page 12 .

4.After chickens start to lay, enter the necessary figures on page 10, and also on pages 11 and 12 .

\section{At close of project:}

a. Fill in figures under "Close of Record" at top of page 5. This includes the Total for Year, all of the expenses on pages 7-9, and all incomes and value on pages 11 and 12 .

b. Fill in the Financial Summary on page 13.

c. Answer questions on page 15 .

d.Be sure to write a story about yourself and your poultry project on page 16 , and include photos on page 17.

\section{Suggestions}

Every club member is expected to study bulletins and other instructions, furnished by the agent to the member. Remember you are in club work to learn how "to make the best better." Read all you can about the type of birds you are raising. Study your birds, watch how they grow, and try to find out which feed gives best results. Learn how to condition your birds and then show them at poultry shows and exhibits. Learn how to select, exhibit, and judge eggs.

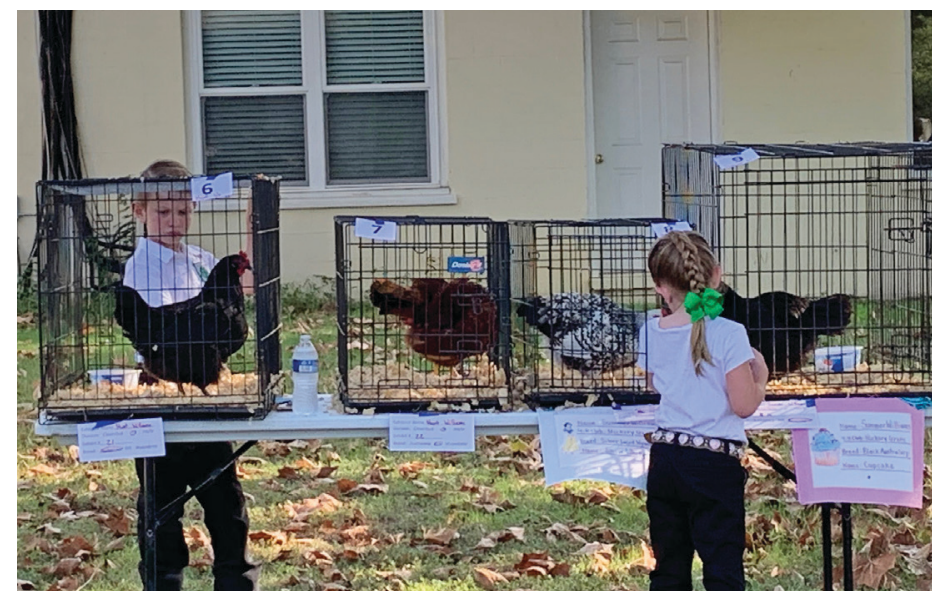

Credit: Elizabeth Moore, UF/IFAS
Remember that the agent is in your county to help you. If you have any trouble, such as your chickens getting off feed or getting sick, let your agent know and he or she will help you.

\section{Opportunities in the 4-H Poultry Project}

There are a number of events and activities available to youth in the 4-H poultry project. These include the 4-H poultry judging contest, the chick chain events, poultry shows, poultry barbecue contest, egg preparation contest, avian bowl, and other educational opportunities.

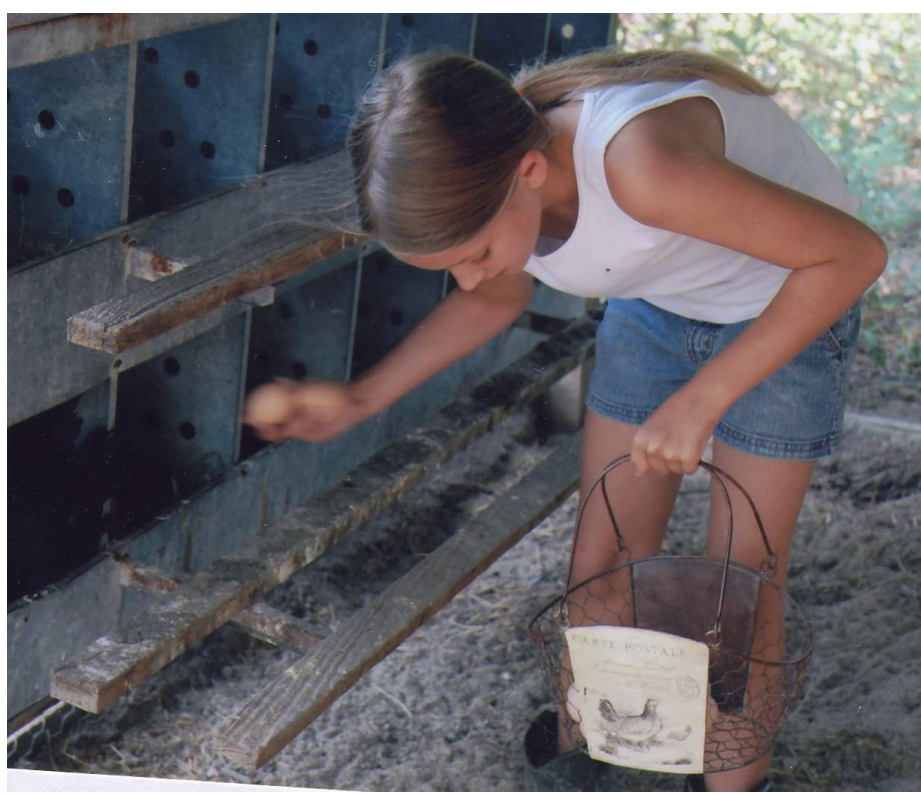

Credit: Chris DeCubellis, UF/IFAS 


\section{Day-Old Chicks Started}

Use this section to keep a record of birds started and raised in the project.

What type of brooder did you use?

\begin{tabular}{|l|l|l|l|l|}
\hline \multirow{2}{*}{ Stock and Equipment } & \multicolumn{2}{c|}{ Beginning of Record } & \multicolumn{2}{c|}{ Close of Record } \\
\cline { 2 - 5 } & Number or Amount & Total Value & Number or Amount & \multicolumn{1}{c|}{ Total Value } \\
\hline Hens & & $\$$ & & $\$$ \\
\hline Pullets & & & & \\
\hline Males for Breeding & & & & \\
\hline Birds for Meat (Broilers) & & & & \\
\hline Chicks under 8 Weeks Old & & & & \\
\hline Total (Stock) & & & & \\
\hline Houses/Pens & & & & \\
\hline Feeders & & & & \\
\hline Waterers & & & & \\
\hline Feed & & & & \\
\hline Supplies & & & & \\
\hline Miscellaneous & & & & \\
\hline Total (Equipment) & & & \\
\hline
\end{tabular}

What types of feed did you use?

\begin{tabular}{|l|l|c|c|}
\hline \multicolumn{1}{|c|}{ Date } & \multicolumn{1}{|c|}{ Breed and Variety } & Number Started & Number Raised \\
\hline $3 / 12 / 20$ & Example: Plymouth Rock, Barred, Pullets & 8 & 7 \\
\hline & & & \\
\hline & & & \\
\hline & & & \\
\hline & & & \\
\hline & & & \\
\hline Total \$ & & & \\
\hline
\end{tabular}

Did you buy straight-run or pullet chicks?

Did you buy any mature birds? 


\section{Summary of Origin and Disposal of Layers}

\begin{tabular}{|l|l|l|l|l|l|l|l|}
\hline \multicolumn{1}{|c|}{ Month } & $\begin{array}{c}\text { \# Layers } \\
\text { Beginning of } \\
\text { Month }\end{array}$ & $\begin{array}{c}\text { Sales During } \\
\text { Month }\end{array}$ & $\begin{array}{c}\text { Deaths } \\
\text { During } \\
\text { Month }\end{array}$ & $\begin{array}{c}\text { Eaten During } \\
\text { Month }\end{array}$ & $\begin{array}{c}\text { Layers Added } \\
\text { During } \\
\text { Month }\end{array}$ & $\begin{array}{c}\text { On Hand End } \\
\text { of Month }\end{array}$ & $\begin{array}{c}\text { Average \# for } \\
\text { Month* }\end{array}$ \\
\hline January & & & & & & & \\
\hline February & & & & & & & \\
\hline March & & & & & & & \\
\hline Mapril & & & & & & & \\
\hline June & & & & & & & \\
\hline July & & & & & & & \\
\hline August & & & & & & & \\
\hline September & & & & & & & \\
\hline October & & & & & & & \\
\hline November & & & & & & & \\
\hline December & & & & & & & \\
\hline Total for Year & $-\cdots---$ & \\
\hline
\end{tabular}

*The average number of layers for each month is obtained by adding the number of birds on hand at the beginning and end of the month and dividing by two (2). For the yearly average, add the twelve monthly averages and divide by twelve (12). The number of layers at the end of each month is the number at the beginning of the month, minus the layers sold, died, or eaten, plus any that might have been added during the month.

KEEP AN ACCURATE RECORD OF ALL LAYERS ADDED, SOLD, DIED, OREATEN. 


\section{Equipment Expenses}

Enter here a record of all of the items and equipment you purchased (except feed) including equipment, medicine, veterinary care/items, and other supplies. Make copies of this page as needed.

\begin{tabular}{|c|c|c|c|c|}
\hline Date & Material/Description & Quantity & Unit Cost & Cost \\
\hline $1 / 5 / 20$ & Example: 3 -foot $\times 150$-foot roll of chicken wire & 2 & $\$ 33.75$ & $\$ 67.50$ \\
\hline & & & & \\
\hline & & & & \\
\hline & & & & \\
\hline & & & & \\
\hline & & & & \\
\hline & & & & \\
\hline & & & & \\
\hline & & & & \\
\hline & & & & \\
\hline & & & & \\
\hline & & & & \\
\hline & & & & \\
\hline & & & & \\
\hline & & & & \\
\hline & & & & \\
\hline & & & & \\
\hline & & & & \\
\hline & & & & \\
\hline & & & & \\
\hline & & & & \\
\hline & & & & \\
\hline & & & & \\
\hline & & & & \\
\hline & & & & \\
\hline & & & & \\
\hline & & & & \\
\hline & & & & \\
\hline
\end{tabular}

Total to be carried forward to Project Financial Summary Total \$ 


\section{Feed Expenses}

Enter here a record of all of feed and nutritional supplement expenses. Include weights in the description. Make copies of this page as needed.

\begin{tabular}{|c|c|c|c|c|}
\hline Date & Material/Description & Quantity & Unit Cost & Cost \\
\hline $1 / 5 / 20$ & Example: $16 \%$ complete layer feed, 50 -pound bag & 4 & $\$ 11.25$ & $\$ 45.00$ \\
\hline & & & & \\
\hline & & & & \\
\hline & & & & \\
\hline & & & & \\
\hline & & & & \\
\hline & & & & \\
\hline & & & & \\
\hline & & & & \\
\hline & & & & \\
\hline & & & & \\
\hline & & & & \\
\hline & & & & \\
\hline & & & & \\
\hline & & & & \\
\hline & & & & \\
\hline & & & & \\
\hline & & & & \\
\hline & & & & \\
\hline & & & & \\
\hline & & & & \\
\hline & & & & \\
\hline & & & & \\
\hline & & & & \\
\hline & & & & \\
\hline & & & & \\
\hline & & & & \\
\hline & & & & \\
\hline & & & & \\
\hline
\end{tabular}

Total to be carried forward to Project Financial Summary Total \$ 


\section{Other Expenses}

Enter here a record of all other expenses. Include the purchase of birds/fertile eggs. Make copies of this page as needed.

\begin{tabular}{|c|c|c|c|c|}
\hline Date & Material/Description & Quantity & Unit Cost & Cost \\
\hline $1 / 5 / 20$ & Example: Rhode Island Red pullet chicks & 10 & $\$ 3.75$ & $\$ 33.75$ \\
\hline & & & & \\
\hline & & & & \\
\hline & & & & \\
\hline & & & & \\
\hline & & & & \\
\hline & & & & \\
\hline & & & & \\
\hline & & & & \\
\hline & & & & \\
\hline & & & & \\
\hline & & & & \\
\hline & & & & \\
\hline & & & & \\
\hline & & & & \\
\hline & & & & \\
\hline & & & & \\
\hline & & & & \\
\hline & & & & \\
\hline & & & & \\
\hline & & & & \\
\hline & & & & \\
\hline & & & & \\
\hline & & & & \\
\hline & & & & \\
\hline & & & & \\
\hline & & & & \\
\hline & & & & \\
\hline
\end{tabular}

Total to be carried forward to Project Financial Summary

Total \$ 


\section{Daily Egg Record}

Use this page to record how many eggs your birds produced each day of the project year.

\begin{tabular}{|c|c|c|c|c|c|c|c|c|c|c|c|c|}
\hline DATE & JAN. & FEB. & MAR. & APR. & MAY & JUNE & JULY & AUG. & SEPT. & ОСТ. & NOV. & DEC. \\
\hline 1 & & & & & & & & & & & & \\
\hline 2 & & & & & & & & & & & & \\
\hline 3 & & & & & & & & & & & & \\
\hline 4 & & & & & & & & & & & & \\
\hline 5 & & & & & & & & & & & & \\
\hline 6 & & & & & & & & & & & & \\
\hline 7 & & & & & & & & & & & & \\
\hline 8 & & & & & & & & & & & & \\
\hline 9 & & & & & & & & & & & & \\
\hline 10 & & & & & & & & & & & & \\
\hline 11 & & & & & & & & & & & & \\
\hline 12 & & & & & & & & & & & & \\
\hline 13 & & & & & & & & & & & & \\
\hline 14 & & & & & & & & & & & & \\
\hline 15 & & & & & & & & & & & & \\
\hline 16 & & & & & & & & & & & & \\
\hline 17 & & & & & & & & & & & & \\
\hline 18 & & & & & & & & & & & & \\
\hline 19 & & & & & & & & & & & & \\
\hline 20 & & & & & & & & & & & & \\
\hline 21 & & & & & & & & & & & & \\
\hline 22 & & & & & & & & & & & & \\
\hline 23 & & & & & & & & & & & & \\
\hline 24 & & & & & & & & & & & & \\
\hline 25 & & & & & & & & & & & & \\
\hline 26 & & & & & & & & & & & & \\
\hline 27 & & & & & & & & & & & & \\
\hline 28 & & & & & & & & & & & & \\
\hline 29 & & & & & & & & & & & & \\
\hline 30 & & & & & & & & & & & & \\
\hline 31 & & & & & & & & & & & & \\
\hline Total \# Eggs & & & & & & & & & & & & \\
\hline${ }^{*}$ Av. \# of Birds & & & & & & & & & & & & \\
\hline ** Av. \# of Eggs Per Bird & & & & & & & & & & & & \\
\hline
\end{tabular}

*The average number of birds is shown on page 5 .

**Divide average number of birds into total number of eggs. 


\section{Income}

Record all items sold related to the project during the year here. This includes eggs sold, birds sold, manure (for fertilizer) sold, or any equipment sold. Also include any show premiums or cash prizes. Make copies of this page as needed.

\begin{tabular}{|c|c|c|c|c|}
\hline Date & Material/Description & Quantity & Unit Cost & Cost \\
\hline $1 / 5 / 20$ & Example: brown eggs (dozen) & 5 & $\$ 4.00$ & $\$ 20.00$ \\
\hline & & & & \\
\hline & & & & \\
\hline & & & & \\
\hline & & & & \\
\hline & & & & \\
\hline & & & & \\
\hline & & & & \\
\hline & & & & \\
\hline & & & & \\
\hline & & & & \\
\hline & & & & \\
\hline & & & & \\
\hline & & & & \\
\hline & & & & \\
\hline & & & & \\
\hline & & & & \\
\hline & & & & \\
\hline & & & & \\
\hline & & & & \\
\hline & & & & \\
\hline & & & & \\
\hline & & & & \\
\hline & & & & \\
\hline & & & & \\
\hline & & & & \\
\hline & & & & \\
\hline & & & & \\
\hline & & & & \\
\hline
\end{tabular}

Total to be carried forward to Project Financial Summary

Total \$ 


\section{Value of Items Produced and Used or Not Sold}

Use this area to record the value of items produced and used or not sold. Do not include animals retained; this is captured in the closing inventory. Make copies of this page as needed.

\begin{tabular}{|c|c|c|c|c|}
\hline Date & Material/Description & Quantity & Unit Cost & Cost \\
\hline $1 / 5 / 20$ & Example: brown eggs (dozen) — consumed by family & 1 & $\$ 4.00$ & $\$ 4.00$ \\
\hline & & & & \\
\hline & & & & \\
\hline & & & & \\
\hline & & & & \\
\hline & & & & \\
\hline & & & & \\
\hline & & & & \\
\hline & & & & \\
\hline & & & & \\
\hline & & & & \\
\hline & & & & \\
\hline & & & & \\
\hline & & & & \\
\hline & & & & \\
\hline & & & & \\
\hline & & & & \\
\hline & & & & \\
\hline & & & & \\
\hline & & & & \\
\hline & & & & \\
\hline & & & & \\
\hline & & & & \\
\hline & & & & \\
\hline & & & & \\
\hline & & & & \\
\hline & & & & \\
\hline
\end{tabular}

Total to be carried forward to Project Financial Summary

Total \$ 


\section{Project Financial Summary}

\section{Fill this out at the end of your project}

\section{Expenses}

Value of animals on hand at start of project

$\$$

Value of equipment on hand at start of project \$

Total equipment expenses

$\$$

Total feed expenses

$\$$

Total other expenses

$\$$

Total Expenses:

\section{Income}

Value of animals on hand at end of project

$\$$

Value of equipment on hand at end of project

$\$$

Income from items/products sold

$\$$

Value of items used or not sold

$\$$

Total Income:

$\$$

\section{Total Profit or Loss}

Total Income - Total Expenses

$\$$ 


\section{National Poultry Improvement Program (NPIP)}

The National Poultry Improvement Program is a national, voluntary program that is a cooperative between federal and state agencies and the poultry industry. It utilizes disease control and prevention strategies in an effort to help improve poultry products produced by NPIPcertified participants. This program was established in the 1930s, and approximately $95 \%$ of all poultry-breeding operations and hatcheries in the United States participate in the NPIP program.

One benefit of the program is that all poultry and poultry products produced under NPIP can be shipped interstate and internationally with fewer restrictions.

If you plan to produce poultry for a number of years, you might consider getting your flock/operation enrolled in the NPIP program. In Florida, contact the Florida Department of Agriculture and Consumer Services at (352) 745-2544, or email PoultryPrograms@ FreshFromFlorida.com. For more information, visit the Florida Department of Agriculture and Consumer Services NPIP website at https://www. freshfromflorida.com/Business-Services/Animals/ Chickens-Poultry/National-Poultry-Improvement-PlanNPIP, and the national NPIP website at http://www. poultryimprovement.org/default.cfm.

\section{Information on Limited Poultry and Egg Operation Requirements}

In Florida, people who want to sell a small number of eggs or dressed poultry, defined by the Florida Department of Agriculture and Consumer Services as less than 30 dozen eggs per week, or fewer than 384 dressed poultry in one week, can apply for an application and request an inspection for permitting. These small operations must have fewer than 1,000 laying hens annually and/or up to 20,000 birds produced for the production and sale of dressed poultry. Currently this permit costs $\$ 110.00$ annually and allows the sale of shell eggs and dressed poultry within the state of Florida without further inspection. Eggs must be washed and air-dried using an egg-washing machine or a sink with three compartments, then kept below $45^{\circ} \mathrm{F}$ before sale. Eggs can be sold in open flats, not cartons, and a sign at least 7 inches by 7 inches must say "These eggs have not been graded as to quality and weight" at the point of sale.

For those wanting to sell dressed broilers or other dressed poultry, producers have to keep these birds below $41^{\circ} \mathrm{F}$ before sale. Producers have to include their name, farm address, the statement "Exempt P.L. 90-492" and required safe food-handling instructions:

- Some food products may contain bacteria that could cause illness if the product is mishandled or cooked improperly. For your protection, follow these safe handling instructions.

- Keep refrigerated or frozen. Thaw in refrigerator or microwave.

- Keep raw meat and poultry separate from other foods. Wash working surfaces (including cutting boards), utensils, and hands after touching raw meat or poultry.

- Cook thoroughly.

- Keep hot foods hot. Refrigerate leftovers immediately or discard.

For more information to get permitted as a small-scale producer of eggs or dressed poultry, visit https://www.freshfromflorida.com/content/ download/64357/1523661/Limited_Poultry_and_Egg_ Operation_Requirements.pdf and http://nwdistrict.ifas. ufl.edu/phag/2017/05/25/what-are-the-requirements-tosell-eggs-and-dressed-poultry-from-florida-small-farms/. 


\section{Questionnaire}

Fill this out at the conclusion of your project before submitting your record book.

1.Were your birds bothered by, or did you have to treat, any of these issues? Check all that apply.

\begin{tabular}{|l|l|l|l|}
\hline Coccidiosis & Lice & \\
\hline Fowl Pox & Fleas & \\
\hline Newcastle & Mites & \\
\hline Bronchitis & Ticks & \\
\hline Leucosis & Worms & \\
\hline Pullet Disease & & Colds & \\
\hline Other Issues & & & \\
\hline
\end{tabular}

2.Is your flock NPIP certified? If so, what is your NPIP number?

3.Did you market any eggs wholesale or retail?

4.Did you market any meat/broilers wholesale or retail?

5.Did you sell any fertile eggs for others to hatch?

6.Did you sell any live birds?

7. What skills did you learn through participating in the 4-H poultry project?

8. Do you plan to have a $4-\mathrm{H}$ poultry project next year?
9. List any community service you did as part of the 4-H poultry project:

10. Did you do a demonstration on your 4-H poultry project? At what levels (club, county, district, or state)?

11. List any county, district, state, or national shows or 4-H events you participated in during this project year.

12. Have you been on a poultry judging team?

13. Have you attended 4-H Summer Camp?

14. Have you attended 4-H University? 


\section{Project Story}

Write a complete story of your year's work. Relate your experiences in taking care of your chickens. Include brooding, feeding, marketing, and anything else about your flock. Include what you have learned about your animal, what safety practices you used in your project, what you could do to improve your project, and the different skills that you used in your project. 


\section{PROJECT PICTURES}

Show the beginning and end of your project along with different skills that you learned while participating in this project. This should include a minimum of four pictures and a maximum of eight pictures. Include a caption with each picture. These captions should tell a story. Make copies of this page as needed. 


\section{Glossary}

Broiler - a fast-growing, muscular chicken used for the production of tender meat.

Broody Hen - a hen that wants to sit on her eggs in order to incubate them.

Capon - a male chicken that has been castrated, usually to improve meat quality.

Chick - a baby chicken of either sex that is recently hatched and still covered in down.

Cockerel-a young male chicken that is not yet mature.

Dual-Purpose - poultry breeds that are useful for both egg production and to be utilized as meat birds.

Flock-a group of poultry living together at one location.

Hen - a fully grown female poultry animal such as a mature female chicken, duck, or turkey.

Pullet - a young female poultry animal that is not yet mature and not old enough to lay eggs.

Non-Setting or Non-Broody Hen-a hen that has no inclination to sit on her eggs in order to incubate them.

Rooster-a mature male chicken.

Straight Run-chicks that have not been separated by sex at hatching and thus are a natural mix of males and females.

\section{Suggested Resources}

Florida 4-H Poultry Curricula Resource Page:

http://florida4h.org/programs/Poultry.pdf

Care of Baby Chicks (DeCubellis, 2007):

https://edis.ifas.ufl.edu/an 182

Common Poultry Diseases (Butcher, Jacob, \& Mather, 1999): https://edis.ifas.ufl.edu/ps044

External Parasites of Poultry (Kaufman, 2019):

https://edis.ifas.ufl.edu/ig140

Factors Affecting Egg Production in Backyard Chicken Flocks (Jacob, Wilson, Miles, Butcher, \& Mather, 2017): http://edis.ifas.ufl.edu/ps029

Intestinal Parasites in Backyard Chicken Flocks (Butcher \& Miles, 1992): https://edis.ifas.ufl.edu/vm015

Small Flock Poultry Nutrition (Davis, 2003): https://ufdc.ufl.edu/IR00008667/00001 